\title{
ANALISIS KEBERLANJUTAN PENGELOLAAN TAMAN WISATA ALAM LAUT (TWAL) PULAU WEH BERDASARKAN HUKOM ADAT LAOT (Sustainability Analysis of the Marine Recreational Park (MRP) Management in Weh Island Based on Local Customary Law of the Sea (Hukom Adat Laot))
}

\author{
Muhammad Aris $^{1}{ }^{*}$, Achmad Fahrudin ${ }^{1}$, Etty Riani $^{1}$, Efin Muttaqin ${ }^{2}$ \\ ${ }^{1}$ Program Studi Pengelolaan Sumber Daya Pesisir dan Lautan, \\ Fakultas Perikanan dan Ilmu Kelautan, Institut Pertanian Bogor, Jl. Raya Darmaga Bogor 16680. \\ ${ }^{2}$ Wildlife Conservation Society (WCS) - Marine Program Indonesia, \\ Jalan Tampomas Ujung No. 35, Babakan, Bogor Tengah - Bogor 16151. \\ *Penulis korespondensi. Tel: 085260011460. Email: akolek50@ gmail.com.
}

Disetujui: 14 Agustus 2017

\begin{abstract}
Abstrak
Taman Wisata Alam Laut (TWAL) Pulau Weh merupakan kawasan konservasi yang dikelola oleh Badan Konservasi Sumber Daya Alam (BKSDA) Banda Aceh. TWA Laut Pulau Weh terletak di Desa Iboih dan masuk ke dalam Wilayah Hukom Adat Panglima Laot Lhok Iboih. Keberadaan Hukom Adat Laot memberikan dampak secara ekologi, sosial ekonomi, dan tata kelola TWA Laut Pulau Weh. Selain itu, sistem pengelolaan berdasarkan hukum adat dapat dijadikan rujukan dalam menyusun kebijakan atau strategi pengeloaan TWA Laut Pulau Weh ke depan. Tujuan dari penelitian ini adalah menghitung dan mengestimasi tingkat keberlanjutan pengelolaan TWA Laut Pulau Weh berdasarkan Hukom Adat Laot Lhok Iboih. Metode yang digunakan adalah multi dimensional scalling (MDS) berdasarkan tiga dimensi yaitu ekologi, sosial ekonomi dan tata kelola. Hasil analisis menunjukkan bahwa dimensi tata kelola dan sosial ekonomi berada pada kategori cukup keberlanjutan dengan indeks 59,98 dan 56,75, sedangkan dimensi ekologi berada pada kategori kurang berkelanjutan dengan indeks 46,94. Indeks dan status keberlanjutan menunjukkan bahwa, sistem pengelolaan berdasarkan Hukom Adat Laot Lhok Iboih pada dimensi tata kelola dan sosial ekonomi cukup memberikan dampak terhadap keberlanjutan pengelolaan TWA Laut Pulau Weh.
\end{abstract}

Kata kunci: Hukom Adat Laot, taman wisata alam, kawasan konservasi, sistem pengelolaan, status keberlanjutan.

\section{Abstract}

Marine Recreational Park (MRP) Weh Island is a conservation area managed by Natural Resources Conservation Agency Banda Aceh. The MRP is located at Iboih village and it is also inside the area of local customary Law of the Sea Lhok Iboih. The existence of customary Law of the Sea affects the management of MRP in terms of ecology and social economy. Apart from that, the local customary management system could be used as a reference in finalizing the policy and strategy of the management of MRP Weh Island in the future. The purpose of this research is to calculate and to estimate the sustainability level of the MRP Weh Island management based on customary Law of the Sea Lhok Iboih. The method used is multi dimensional scaling (MDS) that is based on 3 dimensions i.e. ecology, social economy, and management. The analysis result indicates that the dimension of management and social economy are arguably sustainable with index 59.98 and 56.75, while the dimension of ecology falls into less sustainable level with index 46.94. The index and sustainability status indicate that the management system based on customary Law of the Sea Lhok Iboih specifically on the dimension of management and social economy influence the sustainability of MRP Weh Island management.

Keywords: customary law of the sea, marine recreational park, conservation area, management system, sustainability status.

\section{PENDAHULUAN}

Taman Wisata Alam (TWA) Pulau Weh memiliki status yang jelas ditinjau dari aspek hukum nasional. Awal penetapannya, TWA Pulau Weh diputuskan sebagai kawasan konservasi oleh Kementerian Pertanian Republik Indonesia melalui Surat Keputusan Nomor 928/KPTS/UM/2/1982. Selain berstatus kawasan konservasi, TWA Pulau Weh juga dapat dikategorikan sebagai Kawasan
Pelestarian Alam (KPA) sebagaimana ditetapkan oleh Peraturan Pemerintah Nomor 68 tahun 1998 tentang Kawasan Suaka Alam (KSA) dan Kawasan Pelestarian Alam (KPA). Adanya UU Nomor 5 tahun 1990 tentang Konservasi Sumber Daya Hayati dan Ekosistemnya, maka TWA Pulau Weh berada di bawah kewenangan pengelolaan Kementerian Kehutanan Republik Indonesia dan dikelola oleh Badan Konservasi Sumber Daya 
Alam (BKSDA) Banda Aceh sebagai pelaksana teknis.

TWA Pulau Weh secara administratif terletak di Kota Sabang Provinsi Aceh. Pemerintah Kota Sabang masih mengakui adanya Hukum Adat Laot dalam mengatur dan mengelola kegiatan-kegiatan perikanan tangkap. Aturan-aturannya merupakan adat istiadat, kebiasaan-kebiasaan yang berlaku di bidang penangkapan ikan dan cara menyelesaikan sengketa nelayan. Semua ketentuan yang berlaku dalam hal mengatur dan mengelola perikanan tangkap dikendalikan oleh satu lembaga di kalangan masyarakat Aceh yang dikenal dengan sebutan Lembaga Adat Laot atau Panglima Laot. Lembaga yang sudah berdiri di Kota Sabang, dipimpin oleh seorang ketua yang disebut Panglima Laot (Perda DI Aceh No.7 tahun 2000). Berdasarkan wewenang wilayah pengelolaan, Panglima Laot dibagi menjadi tiga yaitu Panglima Laot Provinsi Aceh, Panglima Laot Kabupaten/Kota, dan Panglima Laot Lhok (teluk) (Qanun Aceh Nomor 10, 2008).

TWA Laut Pulau Weh berada di Desa Iboih dan masuk ke dalam Wilayah Hukom Adat Panglima Laot Lhok Iboih. Hukum Adat Laot yang berlaku di Perairan Iboih dalam konteks pengelolaan ada dua larangan. Larangan pertama adalah larangan penangkapan ikan dengan menggunakan bom (pemboman ikan), menggunakan kompresor, menggunakan pukat, dan penangkapan ikan hias. Larangan kedua yaitu larangan penangkapan ikan/biota dengan menggunakan jaring ikan dan menggunakan senjata tembak ikan (speargun), larangan melakukan penangkapan ikan dengan cara mancing intip maupun melakukan penangkapan ikan/biota pada malam hari.

Pengelolaan oleh Panglima Laot beserta dengan masyarakat telah dilakukan jauh sebelum kawasan tersebut ditetapkan sebagai kawasan konservasi oleh pemerintah pada tahun 1982. Chaliluddin et al. (2014) menyatakan bahwa Panglima Laot merupakan lembaga tradisional tertua di dunia dalam pengelolaan perikanan berbasis kearifan lokal. Panglima Laot Lhok Iboih (PLL Iboih) yang dulunya banyak berurusan dengan aktivitas nelayan dan usaha penangkapan ikan, saat ini lebih fokus pada perlindungan ekosistem pesisir yang ada di wilayah tersebut. Hal ini selain disebabkan oleh keberadaan nelayan di Desa Iboih semakin berkurang karena beralih profesi sebagai pelaku wisata, juga disebabkan oleh kekhawatiran terhadap kerusakan ekosistem pesisir. Cinner dan Aswani (2007) menguatkan pernyataan tersebut dan menjelaskan bahwa penerapan pengelolaan kawasan konservasi secara adat pada umumnya dinamis dan berkembang secara adaptif mencerminkan perubahan sosial, politik, ekonomi dan kondisi budaya.

Ada beberapa isu yang berkembang dalam proses pengelolaan TWA Laut Pulau Weh. Otoritas TWA Pulau Weh menyebutkan bahwa mereka mendapatkan permasalahan dari komunitas lokal dan masyarakat yang memanfaatkan wilayah konservasi tersebut, terutama dalam hal penangkapan ikan. Selain itu, kapasitas dari BKSDA yang terbatas dan banyaknya urusan di hutan menyebabkan pengelolaan TWA Laut Pulau Weh tidak berjalan dengan baik (Kusumawati dan Huang, 2015). Keberadaan Hukom Adat Laot memberikan dampak secara ekologi, sosial ekonomi, dan tata kelola TWA Laut Pulau Weh. Kusumawati dan Huang (2015) menjelaskan bahwa meskipun undang-undang pemerintah merupakan dasar hukum dalam penetapan kawasan konservasi TWA Laut Pulau Weh, tetapi implementasi nyata dalam pengelolaan berdasarkan pada hukum adat.

Dampak pengelolaan TWA Laut Pulau Weh berdasarkan Hukom Adat Laot Lhok Iboh dapat diketahui melalui penentuan status keberlajutan pengelolaan berdasarkan Hukom Adat Laot. Selain itu, sistem pengelolaan berdasarkan hukum adat dapat dijadikan rujukan dalam menyusun kebijakan atau strategi pengeloaan TWA Laut Pulau Weh ke depan. Oleh sebab itu, tujuan dari penelitian ini adalah menghitung dan mengestimasi tingkat keberlanjutan pengelolaan kawasan konservasi TWA Laut Pulau Weh berdasarkan Hukom Adat Laot Lhok Iboih.

\section{METODE PENELITIAN}

\section{Waktu dan Lokasi}

Penelitian ini dilaksanakan pada bulan Februari sampai Maret 2015 di TWA Laut Pulau Weh kota Sabang, Provinsi Aceh. Peta lokasi penelitian disajikan pada Gambar 1.

\section{Prosedur}

Data penelitian ini terdiri dari data primer dan data sekunder. Data primer dikumpulkan dengan metode wawancara mendalam terhadap responden yang dipilih secara purposive sampling. Responden yang dipilih adalah masyarakat yang memiliki keterkaitan dengan kawasan konservasi yaitu nelayan, pelaku wisata, tokoh masyarakat, tokoh adat dan pemerintah desa. Penentuan jumlah responden dilakukan berdasarkan dua pendekatan yaitu apabila populasinya kecil $(\leq 10)$ digunakan pendekatan sensus dan apabila populasinya besar (>10) digunakan pendekatan rule of thumbs (pendekatan aturan statistik, yaitu minimal 30 responden) (Sugiyono, 2011). 


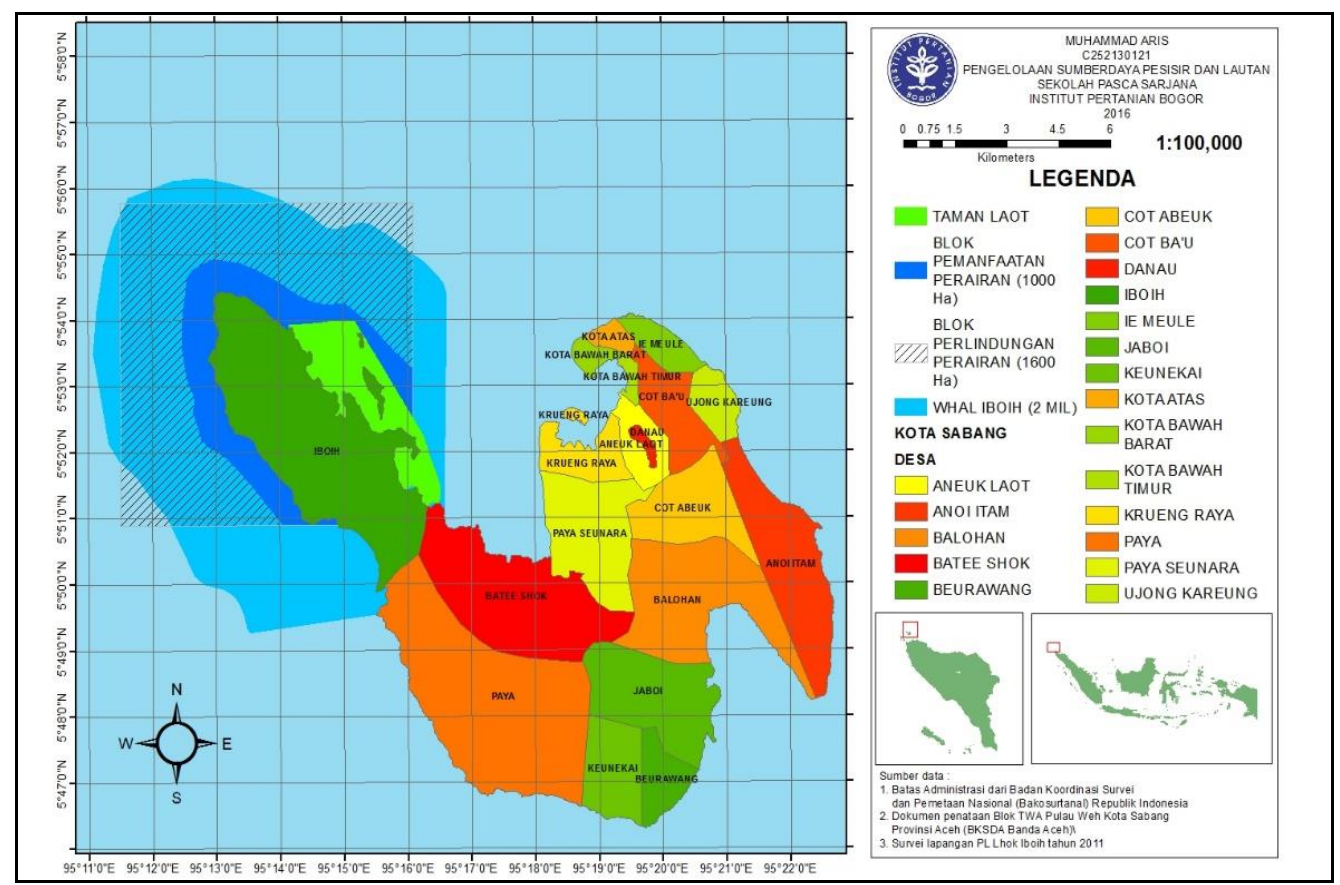

Gambar 1. Lokasi penelitian.

Selain masyarakat, wawancara dilakukan terhadap instansi-instansi yang relevan dengan penelitian ini seperti BKSDA, DKP Kota Sabang dan Resort KSDA Sabang. Data sekunder yang digunakan dalam penelitian ini adalah data ekosistem terumbu karang yang diperoleh dari Wildlife Conservation Society (WCS)-Marine Program Indonesia dan penelitian Muttaqin dkk., (2014).

\section{Analisis Data}

Analisis status keberlanjutan pengelolaan TWA Laut Pulau Weh berdasarkan Hukom Adat Laot Lhok Iboih dilakukan dengan metode analisis statistik Multi Dimensional Scalling (MDS) dengan menggunakan perangkat lunak RAPFISH (Rapid Appraisal Technique for Evaluating Fisheries Sustainability) (Kavanagh dan Pitcer 2004). Analisis multidimensi ini menentukan status keberlanjutan penata kelolaan relatif terhadap dua titik acuan utama yaitu titik "baik" (good) dan titik "buruk" (bad). Untuk mengetahui keberlanjutan pengelolaan TWA Laut Pulau Weh maka digunakan tiga dimensi yaitu ekologi, sosial ekonomi, dan tata kelola. Setiap dimensi terdiri dari beberapa atribut yang diberi skor sesuai dengan kondisi yang diperoleh dari hasil penelitian.

Terdapat beberapa tahapan untuk melakukan analisis menggunakan MDS. Pertama, menentukan terlebih dahulu dimensi dan atribut keberlanjutan. Kedua, memberikan skor untuk setiap atribut, pemberian skor pada setiap atribut dapat menggambarkan kondisi keberlanjutan pengelolaan TWA Laut Pulau Weh, apakah baik atau buruk. Tahapan ketiga, ordinasi RAPFISH dengan tujuan untuk menentukan satu titik (nilai) yang dapat
Tabel 1. Indeks dan kategori status keberlanjutan.

\begin{tabular}{cl}
\hline Skala indeks & \multicolumn{1}{c}{ Kategori } \\
\hline $0.00-25.00$ & Buruk (tidak berkelanjutan) \\
$25,01-50,00$ & Kurang (kurang berkelanjutan) \\
$50,01-75.00$ & Cukup (cukup berkelanjutan) \\
$75.01-100.00$ & Baik (sangat berkelanjutan) \\
\hline
\end{tabular}

menggambarkan posisi relatif dari pengelolaan TWAL Pulau Weh dengan nilai stress (S) dan koefisien determinasi $\left(\mathrm{R}^{2}\right)$ untuk mengukur goodness of fit.

Hasil analisis yang baik ditunjukan dengan nilai stress lebih kecil dari $0.25(\mathrm{~S}<0.25)$ dan nilai $\mathrm{R}^{2}$ lebih tinggi (Fauzi dan Anna, 2002). Keempat, menentukan status keberlanjutan pengelolaan dengan menggunakan kategori keberlanjutan mengacu pada Fauzi dan Anna (2005) seperti disajikan pada Tabel 1. Tahapan selanjutnya adalah analisis Monte Carlo yang digunakan untuk mengetahui kestabilan hasil ordinasi RAPFISH yang dilakukan sebanyak 25 kali ulangan dengan teknik scatter plot. Kestabilan indeks keberlanjutan yang dihasilkan digambarkan oleh plot yang berkumpul, jika hasil menunjukkan plot tidak berkumpul atau tersebar diartikan terdapat gangguan atau ketidakpastian dalam hasil analisis. Langkah terakhir adalah analisis leverage untuk mengetahui atribut yang sensitif dari dimensi yang digunakan.

\section{HASIL DAN PEMBAHASAN}

\section{Keberlanjutan Dimensi Ekologi}

Dimensi ekologi mempunyai lima atribut untuk analisis keberlanjutan. Dari hasil analisis 


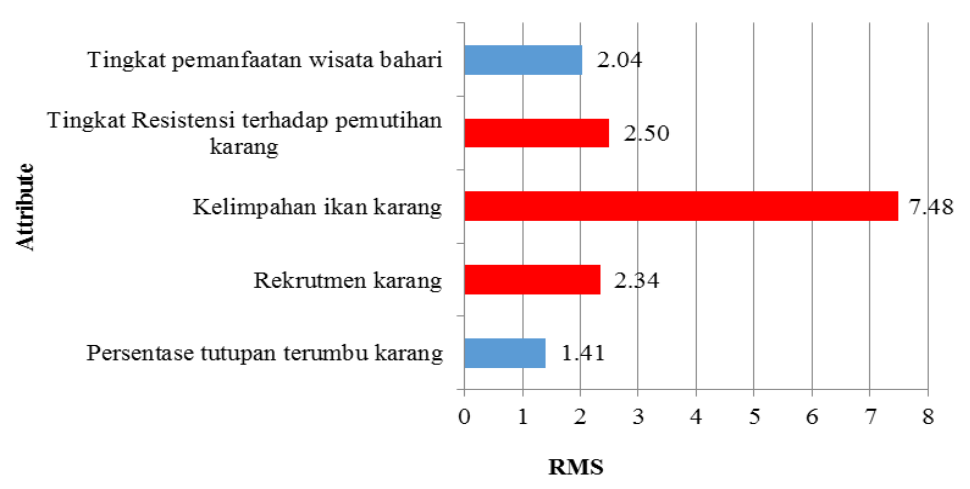

Gambar 2. Analisis leverage factor dimensi ekologi.

RAPFISH menunjukkan bahwa indeks keberlanjutan untuk dimensi ekologi adalah 46,94. Indeks keberlanjutan dimensi ekologi ini dikategorikan kurang berkelanjutan (berada pada selang 26,00-50,00). Koefisien determinasi $\left(\mathrm{R}^{2}\right)$ menunjukkan nilai 0,933 , artinya hasil estimasi proporsi ragam data yang dapat dijelaskan dengan teknik analisis ini terindikasi memadai (>90\%). Nilai stress yang dihasilkan sebesar 0,1668 yang menggambar ketepatan (goodness of fit) dalam kategori cukup baik karena kurang dari 0,25. Menurut Hardle dan Simar (2007), nilai stress yang lebih kecil dari 0,20 tidak menunjukkan goodness of fit yang tergolong buruk.

Hasil analisis leverage factor dimensi ekologi diperoleh tiga atribut yang keberadaannya berpengaruh sensitif terhadap peningkatan atau penurunan status keberlanjutan. Atribut-atribut yang sensitif adalah atribut kelimpahan ikan karang dengan root mean square (RMS) 7,48, atribut tingkat resistensi terhadap pemutihan karang dengan RMS 2,50, dan atribut rekrutmen karang dengan RMS 2,34 (Gambar 2). Nilai RMS paling kecil berada pada atribut persentase tutupan karang yaitu 1,41 .

Atribut kelimpahan ikan karang memiliki tingkat sensivitas yang paling tinggi dibandingkan dengan empat atribut lainya. Ikan karang dan terumbu karang memiliki hubungan dan keterkaitan yang erat. Kelimpahan ikan karang pada ekosistem terumbu karang mencirikan kondisi dari terumbu karang, karena ikan karang akan merespon terhadap perubahan dalam ekosistem terumbu karang, demikian juga sebaliknya, di mana terumbu karang dipengaruhi oleh perkembangan populasi ikan karang (Muttaqin dkk., 2014).

Banyak faktor yang menyebabkan terjadinya pemutihan karang, selain dari faktor alam, pemutihan karang juga dapat terjadi akibat dari kegiatan manusia seperti sedimentasi, polusi serta penangkapan ikan dengan menggunakan potasium maupun bahan peledak. Namun, di TWA Laut Pulau Weh pernah terjadi peristiwa pemutihan karang massal yang menyebabkan Penurunan persentase penutupan terumbu karang yang terjadi setiap tahunnya dipengaruhi oleh peristiwa pemutihan karang yang terjadi pada tahun 2010 di Pulau Weh (Muttaqin dkk., 2014), termasuk proses kerusakan akibat tsunami (Purbani, 2014). Bridge (2013) menyebutkan bahwa pada bulan Mei-Juni 2010 peningkatan suhu permukaan laut di Laut Andaman dan Laut Cina Selatan menyebabkan terjadinya pemutihan karang secara luas dan menyebabkan tingginya kematian dari spesies karang. Total $45 \%$ dari karang yang ada di Pulau Weh mengalami kematian, $94 \%$ dari koloni karang Acropora dan $87 \%$ dari koloni karang Pocillopora mengalami kematian (Guest 2012). Penurunan persentase tutupan karang selain oleh faktor alam, diduga disebabkan oleh faktor antropogenik seperti penggunaan jaring dan potasium.

Kematian karang akibat pemutihan dipengaruhi oleh komposisi genera karang. Marshall dan Baird (2000) menguatkan penyataan tersebut dan menjelaskan bahwa karang bercabang dan memiliki pertumbuhan yang cepat seperti Acropora, Seriatopora, Stylophora, Millepora dan Pocillopora cenderung memiliki tingkat kematian yang tinggi terhadap pemutihan karang dibandingkan dengan karang kompak dengan pertumbuhan yang lambat seperti Favia, Favites, Goniastrea, Astreopora dan Turbinaria. Muliari et.al (2013) menggambarkan komposisi karang keras di TWA Laut Pulau Weh pada tahun 2009 meliputi Porites 30\%, Acropora 26\%, Pocillopora 6\%, Montipora 6\%, Leptastrea 5\%, Favites 4\%, Favia 3\%, Galaxea 2\%, Hydnophora 2\%, Pavona 1 $\%$ dan lain-lain $15 \%$.

Atribut rekrutment karang juga memiliki tingkat sensitivitas yang tinggi. Kemampuan rekruitmen karang pada suatu sistem terumbu karang sangat penting untuk mempertahankan eksistensi dan keberlanjutan dari populasi secara terus menerus dari kerusakan akibat pengaruh lingkungan maupun antropogenik. Hal ini dipahami bahwa kemampuan rekrutmen karang merupakan kemampuan dari suatu koloni individual atau suatu sistem terumbu karang untuk mempertahankan diri 
dari dampak lingkungan, menjaga kemampuan pemulihan dan perkembangan.

\section{Keberlanjutan Dimensi Sosial Ekonomi}

Berdasarkan hasil analisis dengan menggunakan RAPFISH terhadap tujuh atribut yang berpengaruh dalam dimensi sosial ekonomi, menunjukkan indeks keberlanjutan sebesar 56,75. Indeks keberlanjutan ini termasuk dalam kategori cukup berkelanjutan. Koefisien determinasi $\left(\mathrm{R}^{2}\right)$ menunjukkan nilai 0,944, artinya hasil estimasi proporsi ragam data yang dapat dijelaskan dengan teknik analisis ini terindikasi memadai (>90\%). Nilai stress yang dihasilkan sebesar 0,1505 yang menggambar ketepatan (goodness of fit) dalam kategori cukup baik karena kurang dari 0,25. Indeks keberlanjutan dimensi sosial ekonomi menggambarkan bahwa kondisi sosial ekonomi cukup memberi dukungan terhadap pengembangan sistem pengelolaan kawasan secara berkelanjutan, tentunya dengan terus meningkatkan upaya pengelolaannya.

Hasil analisis leverage keberlanjutan dimensi sosial ekonomi dapat dilihat pada Gambar 3. Dari delapan atribut yang dianalisis, diperoleh tiga atribut yang paling sensitif terhadap indeks keberlanjutan dimensi ini, yaitu atribut pemahaman di tingkat lokal terhadap aturan dan sanksi dengan root mean square (RMS) 2,84, dukungan masyarakat terhadap pengelolaan dengan nilai RMS 2,07, dan atribut ketergantungan masyarakat terhadap kawasan dengan nilai RMS 1,78 .

Pemahaman masyarakat terhadap aturan dan sanksi serta dukungan masyarakat terhadap pengelolaan merupakan kunci utama untuk mencapai tujuan dari pengelolaan. Masyarakat harus paham terhadap kegiatan-kegiatan yang dilarang dan kegiatan-kegiatan yang diijinkan untuk dilakukan karena masyarakat berada di garis terdepan dalam pemanfaatan maupun perlindungan sumber daya alam. Campbell et al. (2012) menyebutkan bahwa pembatasan dalam penggunaan alat tangkap jaring pada pengelolaan berbasis adat Panglima Laot berhasil mengurangi kerusakan habitat dan mempertahankan biomassa ikan. Aturan dan sanksi Hukom Adat Laot Lhok Iboih ditampilkan pada Tabel 2.

Ketergantungan masyarakat terhadap kawasan dilihat dari mata pencarian yang berkaitan dengan ekosistem. Sebagian besar bekerja sebagai pelaku wisata, ketergantungan masyarakat terhadap kawasan bisa berdampak positif dan bisa juga berdampak negatif terhadap kondisi sosial ekonomi dan ekologi. Ketergantungan masyarakat terhadap kawasan dapat mendorong masyarakat untuk melindungi kawasan secara intensif dari kerusakan antropogenik. Ketergantungan masyarakat yang tinggi bisa berdampak negatif apabila pemanfaatan ekosistem terumbu karang dilakukan secara berlebihan dengan tidak memperhatikan daya dukung serta masih berorientasi pada keuntungan.

\section{Keberlanjutan Dimensi Tata Kelola}

Hasil analisis RAPFISH terhadap tujuh atribut dalam dimensi tata kelola menunjukkan indeks keberlanjutan sebesar 59,98. Indeks keberlanjutan ini termasuk dalam kategori cukup berkelanjutan (berada dalam selang 51,00 - 75,00). Koefisien determinasi $\left(\mathrm{R}^{2}\right)$ menunjukkan nilai 0.950 , artinya hasil estimasi proporsi ragam data yang dapat dijelaskan dengan teknik analisis ini terindikasi memadai (>90\%). Nilai stress yang dihasilkan sebesar 0,1387 yang menggambar ketepatan (goodness of fit) dalam kategori cukup baik karena kurang dari 0,25. Kategori cukup berkeberlanjutan dari dimensi pengelolaan ini merupakan satusatunya dimensi yang memiliki indeks yang paling tinggi dibandingkan dengan dimensi ekologi dan dimensi sosial ekonomi. Kondisi tersebut menunjukkan bahwa dimensi pengelolaan masih memberi dukungan terhadap keberlanjutan pengelolaan, tentunya upaya untuk meningkatkan pengelolaan harus dilakukan lebih besar lagi.

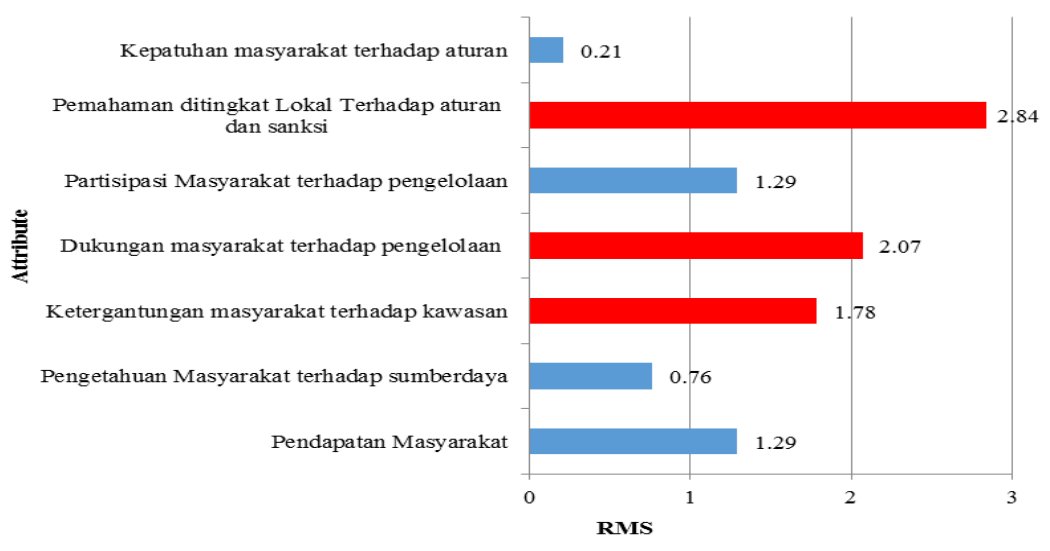

Gambar 3. Analisis leverage factor dimensi sosial ekonomi. 
Tabel 2. Aturan dan sanksi Hukom Adat Laot Lhok Iboih.

\begin{tabular}{lll}
\hline \multicolumn{1}{c}{ Aturan } & \multicolumn{1}{c}{ Sanksi } & \multicolumn{1}{c}{ Area } \\
\hline $\begin{array}{l}\text { Penangkapan ikan hanya boleh dilakukan dengan } \\
\text { cara memancing, menggunakan alat pancing. }\end{array}$ & $\begin{array}{l}\text { Seluruh alat tangkap disita } \\
\text { dan pelaku pelanggaran } \\
\text { diserahkan kepada pihak } \\
\text { berwajib } \\
\text { dan potasium. }\end{array}$ & $\begin{array}{l}\text { Seluruh wilayah Hukom } \\
\text { Adat Lhok Iboih }\end{array}$ \\
\hline $\begin{array}{l}\text { Penangkapan ikan/biota tidak boleh menggunakan } \\
\text { jaring }\end{array}$ & $\begin{array}{l}\text { Denda Rp.10.000.000, kapal } \\
\text { dan alat tangkap akan disita } \\
\text { selama satu minggu }\end{array}$ & $\begin{array}{l}\text { Taman Laut Desa Iboih } \\
\text { (disebut zona inti wilayah } \\
\text { Hukom Adat Laot Lhok } \\
\text { Iboih) }\end{array}$ \\
$\begin{array}{l}\text { Penangkapan ikan/biota tidak boleh menggunakan } \\
\text { speargun. Penangkapan ikan juga tidak boleh } \\
\text { dilakukan dengan cara mancing intip serta } \\
\text { dilakukan pada malam hari }\end{array}$ & $\begin{array}{l}\text { Denda Rp. 1.000.000, alat } \\
\text { tangkap disita. }\end{array}$ & $\begin{array}{l}\text { Taman Laut Desa Iboih } \\
\text { (disebut zona inti wilayah } \\
\text { Hukom Adat Laot Lhok }\end{array}$ \\
\hline
\end{tabular}

Hari pantang melaut/tidak boleh melakukan

aktivitas laut pada hari :

1. Hari Raya Puasa (Idul Fitri) tidak dibenarkan ada kegiatan di laut selama satu hari

2. Hari Raya Haji (Idul Adha) tidak dibenarkan ada kegiatan di laut selama satu hari.

3. Memperingati hari tsunami, tidak dibenarkan ada kegiatan di laut sebelum selesai acara peringatan.

4. Memperingati Kemerdekaan Republik Indonesia setiap tanggal 17 Agustus, tidak dibenarkan ada kegiatan di laut sebelum acara selesai

Hari Jumat, tidak dibenarkan ada kegiatan di laut dari jam 19.00 Hari Kamis sampai dengan selesai Shalat Jum'at termasuk kegiatan snorkling dan diving.

Hari diadakan Kenduri Laot (syukuran), tidak dibenarkan ada kegiatan di laut selama tiga hari.

Denda satu ekor kambing

Seluruh wilayah Hukom Adat Lhok Iboih

$\begin{array}{ll}\text { Kapal dan peralatan melaut } & \text { Seluruh wilayah Hukom } \\ \text { ditahan satu minggu. } & \text { Adat Lhok Iboih }\end{array}$
ditahan satu minggu. Adat Lhok Iboih
Seluruh wilayah Hukom Adat Lhok Iboih ulang.

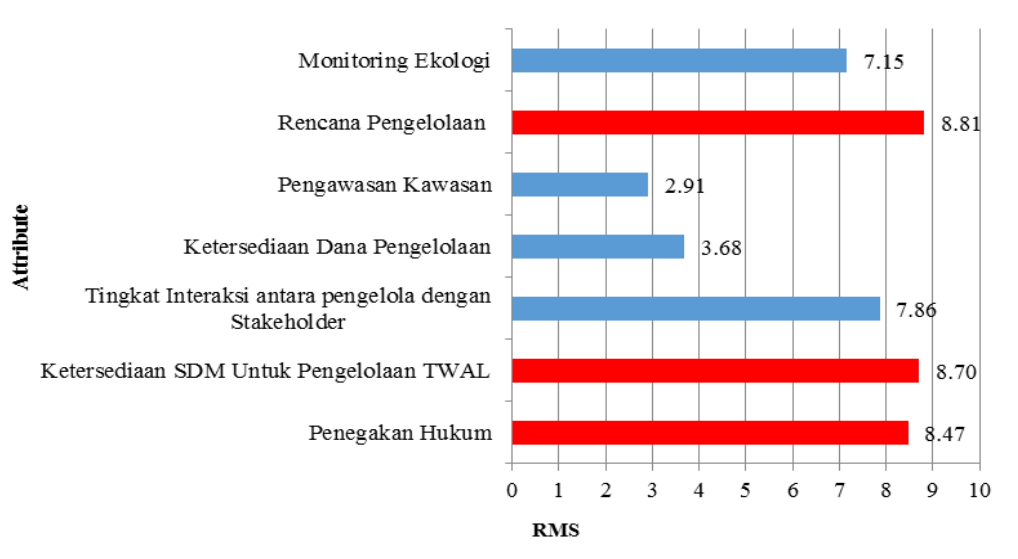

Gambar 4. Analisis leverage factor dimensi tata kelola.

Hasil analisis leverage factor dimensi tata kelola (Gambar 4), terlihat bahwa dari tujuh atribut yang mempengaruhi dimensi ini, ada tiga atribut yang sensitif dan perlu mendapat perhatian yaitu, atribut rencana pengelolaan $(\mathrm{RMS}=8,81)$, atribut ketersediaan sumber daya manusia untuk pengelolaan $(\mathrm{RMS}=8,70)$, dan atribut penegakan hukum $(\mathrm{RMS}=8,47)$.
Tiga atribut yang sensitif tersebut dapat memberikan kontribusi yang besar terhadap eksistensi dari pengelolaan. Adanya rencana pengelolaan sebagai pedoman memberikan kemudahan untuk melaksanakan kegiatan pengelolaan secara terukur dan akurat sesuai dengan tujuan dan program kerja yang telah disusun. Rencana pengelolaan tentu membutuhkan 
Tabel 3. Jenis pelanggaran dan sanksi tahun 2010-2014

\begin{tabular}{|c|c|c|c|}
\hline Waktu kejadian & Jenis pelanggaran & Sanksi & Asal pelaku \\
\hline Oktober 2009 & $\begin{array}{l}\text { Menggunakan alat tangkap } \\
\text { jaring }\end{array}$ & Rp. 10.000 .000 & $\begin{array}{l}\text { Nelayan Lhok Pasiran, } \\
\text { Sabang }\end{array}$ \\
\hline November 2009 & $\begin{array}{l}\text { Menggunakan speargun di } \\
\text { kawasan taman laut }\end{array}$ & Rp. 1.000 .000 & $\begin{array}{l}\text { Warga nelayan Lhok Krueng } \\
\text { Raya, Sabang }\end{array}$ \\
\hline 2010 & $\begin{array}{l}\text { Menggunakan alat tangkap } \\
\text { jaring }\end{array}$ & $\begin{array}{l}\text { Rp. } 10.000 .000 \text { dan alat } \\
\text { tangkap disita } 2 \text { tahun }\end{array}$ & $\begin{array}{l}\text { Gampong (desa) Kota Bawah } \\
\text { Timur, Sabang }\end{array}$ \\
\hline Mei 2011 & $\begin{array}{l}\text { Pengambilan biota laut } \\
\text { dengan alat tangkap yang } \\
\text { dilarang }\end{array}$ & Rp. 100.000 & - \\
\hline November 2011 & $\begin{array}{l}\text { Penangkapan gurita dengan } \\
\text { alat tangkap yang dilarang }\end{array}$ & $\begin{array}{l}\text { Rp. } 100.000 \text { dan alat } \\
\text { tangkap disita } 9 \text { hari }\end{array}$ & $\begin{array}{l}\text { Jurong Bypass Cot Ba'u, } \\
\text { Sabang }\end{array}$ \\
\hline November 2011 & $\begin{array}{l}\text { Pengambilan udang dengan } \\
\text { alat tangkap yang dilarang }\end{array}$ & $\begin{array}{l}\text { Rp. } 100.000 \text { dan alat } \\
\text { tangkap disita } 1 \text { minggu }\end{array}$ & \\
\hline November 2011 & Memasang jaring pantai & $\begin{array}{l}\text { Rp. } 50.000 \text { dan alat } \\
\text { tangkap disita } 1 \text { minggu }\end{array}$ & $\begin{array}{l}\text { Tepi Layeu Desa Iboih, } \\
\text { Sabang }\end{array}$ \\
\hline 2011 & $\begin{array}{l}\text { Penangkapan ikan dengan } \\
\text { cara menombak/menembak }\end{array}$ & $\begin{array}{l}\text { Rp. } 1.000 .000 \text { dan alat } \\
\text { tangkap disita } 10 \text { jam }\end{array}$ & Wisatawan Asing \\
\hline Januari 2012 & $\begin{array}{l}\text { Penangkapan ikan dengan } \\
\text { cara menembak (Speargun) }\end{array}$ & Rp. 1.000 .000 & $\begin{array}{l}\text { Teupi Layeu Desa Iboih, } \\
\text { Sabang }\end{array}$ \\
\hline $\begin{array}{l}\text { Septermber } \\
2013\end{array}$ & $\begin{array}{l}\text { Memancing pada malam } \\
\text { Jum'at }\end{array}$ & $\begin{array}{l}\text { Rp. } 100.000 \text { dan alat } \\
\text { tangkap disita } 1 \text { minggu }\end{array}$ & \\
\hline Juni 2014 & $\begin{array}{l}\text { Pengambilan biota laut } \\
\text { dengan alat tangkap yang } \\
\text { dilarang }\end{array}$ & $\begin{array}{l}\text { Rp. } 500.000 \text { dan alat } \\
\text { tangkap disita selama } 1 \\
\text { bulan }\end{array}$ & - \\
\hline
\end{tabular}

implementasi terhadap program kerja yang telah disusun. Implementasi membutuh kan sumber daya manusia yang handal untuk mencapai hasil yang maksimal. Adanya rencana pengelolaan dan sumber daya manusia tentu tidak cukup tanpa adanya ketegasan dalam penegakan hukum. Aturan-aturan yang telah disusun di upayakan dipatuhi oleh masyarakat dengan menindak tegas terhadap kegiatan-kegiatan pelanggaran. Berdasarkan laporan dari Panglima Laot Lhok Iboih, telah terjadi 11 kali pelanggaran yang berhasil ditangkap dan ditindak lanjuti dari tahun 2010-2014 (Tabel 3)

\section{KESIMPULAN}

Dimensi tata kelola dan dimensi sosial ekonomi memiliki indeks cukup tinggi dengan kategori cukup berkelanjutan, namun dimensi ekologi kurang berkelanjutan. Peristiwa pemutihan karang yang terjadi pada tahun 2010 merupakan salah satu penyebab dimensi ekologi berada pada kategori kurang berkelanjutan.

Tingginya status keberlanjutan pada dimensi tata kelola dan dimensi sosial ekonomi dipengaruhi oleh konsistensi Panglima Laot Lhok Iboih beserta masyarakat dalam melindungi dan memanfaatkan sumber daya alam yang ada di TWA Laut Pulau Weh secara berkelanjutan. Oleh sebab itu, sistem pengelolaan berdasarkan Hukom Adat Laoh Lhok Iboih cukup memberikan dampak terhadap keberlanjutan pengelolaan TWA Laut Pulau Weh.

\section{DAFTAR PUSTAKA}

Bridge, L.C.T., Hoey, S.A., Campbell, J.S., Muttaqin, E., Rudi, E., Fadli, N., and Baird, H.A., 2013. Depth-Dependent Mortality of Reef Corals Following a Severe Bleaching Event: Implications for Thermal Refuges and Population Recovery. F1000Research, 2:18.

Campbell, S.J., Cinner, J.E., Ardiwijaya, R.L., Pardede, S., Kartawijaya, T., Mukmunin, A., Herdiana, Y., Hoey, A.S., Pratchett, M.S., and Bairdet, A.H., 2012. Avoiding Conflicts and Protecting Coral Reefs: Customary Management Benefits Marine Habitats and Fish Biomass. Oryx. 46 (04):486-494.

Chaliluddin, Purbayanto, A., Monintja, R.D., Imron, M., dan Santoso, J., 2014. Intitution of Panglima Laot in Supporting Sustainable Capture Fisheries Base on Local Wisdom in Aceh Jaya District. International Journal of Sciences: Basic and Applied Research, 16(2):2307-4531.

Cinner, E.J., and Aswani, S., 2007. Integrating Customary Management Into Marine 
Conservation. Journal of Biological Conservation, 140:201-216.

Fauzy, A., dan Anna, S., 2002, Evaluasi Status Keberlanjutan Pembangunan Perikanan: Aplikasi Pendekatan RAPFISH (Studi Kasus Perairan Pesisir DKI Jakarta). Jurnal Pesisir dan Lautan, 4(3):43 - 55.

Fauzi, A., dan Anna, S., 2005. Permodelan Sumberdaya Perikanan dan Kelautan Untuk Analisis Kebijakan. PT Gramedia Pustaka Utama. Jakarta

Guest, R.J., Baird, H.A., Maynard, A.J., Muttaqin, E., Edwards, J.A., Campbell, J.S., Yewdall, K., Affendi, A.Y., and Chou, M.L., 2012. Contrasting Patterns of Coral Bleaching Susceptibility in 2010 Suggest An Adaptive Response o Thermal Stress. PloS ONE. 7(3):e33353.

Hardle, W., and Simar, L., 2007. Applied Multivariate Statistical Analysis. Second Edition.Berlin Heidelberg: Springer.

Kavanagh, P., and Pitcher, T.J., 2004. Implementing Microsoft Excel Software for RAPFISH: A Technique for The Rapid Appraisal of Fisheries Status Fisheries. Centre Research Reports, 12:1-80

Kusumawati, I., and Huang, W.H., 2015. Key Factors for Successful Management of Marine Protected Areas: A Comparison Of
Stakeholders' Perception of Two MPAs in Weh Island, Sabang, Aceh, Indonesia. Journal of Marine Policy, 51:465-475.

Marshall, P., and Baird, A.H., 2000. Bleaching of Corals on the Great Barrier Reef: Differential Susceptibilities Among Taxa. Coral Reefs, 19:15-163.

Muliari, Dedi, S., Neviaty, P.Z., dan Yudi, H., 2013. Study of Coral Reef After Tsunami in Weh and Aceh Islands Waters. Jurnal Pendidikan Almuslim, 1(1).

Muttaqin, E., Kamal, M.M., Haryadi, S., Pardede, S., Tarigan, S., and Campbell, S.J., 2014. Dampak Pemutihan Karang Terhadap Ekosistem Terumbu Kararang Pada Tahun 2010 di Perairan Utara Aceh. Jurnal Teknologi Perikanan dan kelautan, 5(1):15-21.

Peraturan Daerah Aceh, 2000. Peraturan Daerah Provinsi Istimewa Aceh Nomor 7 Tahun 2000 tentang Penyelenggaraan Kehidupan Adat.

Purbani, D., Kepel, T.L., dan Takwir, A. 2015. Kondisi Terumbu Karang di Pulau Weh Pasca Bencana Mega Tsunami. J. Manusia \& Lingkungan, 21(3):331-340.

Qanun, 2008. Qanun Aceh Nomor 10 Tahun 2008 tentang Lembaga Adat.

Sugiyono, 2011. Statistika untuk Penelitian. Alfabeta. Bandung. 